\title{
Commentary
}

\section{The University of Hard Knocks: Higher education and social inclusion}

\section{Susanna Chamberlain}

\section{Griffith University}

Traditionally, the Higher Education system has paradoxically been the bastion of social exclusion and the source of ideas that challenge and demand inclusion for many elements of society. This discussion paper explores three aspects of the relationships between social inclusion and higher education: policy, curriculum and practice, but begins by looking at the historical context.

From the time that universities were first established in what we now call the West, their primary function was to uphold a specific social order, giving primacy to particular segments of society and excluding all others. Although the first universities were established in North Africa (Fez and Cairo were both functioning by $900 \mathrm{CE}$ ), it was not until the $11^{\text {th }}$ century that universities were established in Europe. With the establishment of the University of Bologna in 1088, the fundamental lines of possibility for higher education were set out. Bologna began as a law school, entry was only available to males, usually of the aristocracy, and mainly those who would enter the church or make a life's work out of serving the prince or state.

Oxford, Cambridge, and Paris followed within a century, establishing institutions along monastic lines, although claiming autonomy from the Church. The flowering of the medieval university was supported by funds delivered as a result of the Crusades. This is one of the first of the paradoxes of higher education and practices of inclusion: the new disciplines being brought to light in these European universities (mathematics, astronomy, alchemy, even medicine) often derived from knowledges captured along with more mundane treasure from the Muslim universities; however, with a few notable exceptions, few of the people from those conquests were permitted to enter the universities. There were, of course, some great teachers and the works of Avicenna (Ibn Sina), or the teachings of Averroes (Ibn Rusd) were part of the curriculum in this period.

The Crusades also brought the works of Aristotle to Europe to be translated into Latin and used as the basis of learning for the next eight hundred years. Aristotle, of course, believed that women could not be citizens because they had no souls and they could not think rationally. Universities which ascribed to Aristotle the basis of all wisdom, were unable to contradict such a fundamental principle in their practice. Women could not be admitted to higher education on the basis that they were incapable of higher thought. There were some exceptions: Helena Piscopia managed to win a Doctorate in 
Philosophy in 1678 from the University of Padua. She was a wealthy Venetian aristocrat and Venice seems to have encouraged women to undertake learning (Veronica Franco the famous courtesan -poet) as did many of the Italian city-states of the $16^{\text {th }}$ Century. Elizabeth I of England, Isabella of Spain, Isabella D'este, and a handful of others have come to be known for their scholarship. These were aristocrats, educated privately and with the sole exception of Helena, excluded from Universities.

It would take until the late $19^{\text {th }}$ Century before women were admitted to universities, and even later before some universities would grant them degrees (Oxford 1920, Cambridge 1948). In contrast to the conservatism of the British universities, Australian women graduated as early as 1883 ( Bella Guerin, BA, University of Melbourne) and in the sciences (Edith Dornwell 1885 University of Adelaide). Perhaps the strength of women's suffrage in Australia and the vote at Federation in 1901 owed something to the inclusion of women in the universities- education providing a powerful tool in achieving a measure of electoral equality.

With the discovery of the "New World", the establishment of the higher education sector took a new turn. Many of the establishments were commercially based and often founded as a result of a philanthropic bequest which found its source in the fortune of the Protestant Capitalism of the post-Reformation movement towards modernity. While entrance was still restricted to white men of particular social classes, now the additional factor became the financial investment required for a son to be educated. This kind of education had social consequences- a man who had been to university could be trusted to manage business, nation, and empire. He was "one of us"- a marker that was exaggerated in those places that chose to build in secret societies or fraternities to further exclude the unworthy from potential power.

Until the late $19^{\text {th }}$ Century, women and the poor were excluded from higher education. But so were a range of other groups. With the dominant ideology of mens sana in corporo sane, and the passion for sporting pursuits, even among the aristocracy or the wealthy upper middle class, those who were "halt, lame or blind" could not hope to be included in Higher education until the latter part of the twentieth century.

With the changing face of the political spheres of influence in the mid-twentieth century, a new foundation of universities occurred as former colonial nations became independent and set up their own education systems. One of the excluded groups had been people of colour; even the very rich had found it difficult to be accepted into the established universities in the English-speaking world although some European universities had been more accepting. There are scholars exploring the issues surrounding people of colour in predominantly white institutions, and of the impact of the dominance of the British education system across the former Empire (Milner-Thornton 2012).

Historically, universities have served to circumscribe the insiders of society, based on gender, colour, class, status and ability. They have also served to exclude all who did not fit the prescribed profile. The gradual process of inclusion into higher 
education in the West of women, people of colour, people from poorer classes and those with disabilities has taken over a century, but is not yet unproblematic.

There are three aspects of the relationship between social inclusion and higher education that deserve some further exploration: policy, curriculum and practice. The policy of social inclusion is generated at three levels: government, university and the school, faculty or group that directly manages an element of the institution.

In Australia, taking the lead from the EU, the current government social inclusion policy focuses (DEEWR 2009) upon Levitas' paper (2003 cited in DEEWR 2009) to indicate three significant elements of "exclusion": 1, the ability to participate in the "customary life of the society", i.e. poverty; 2,entry into the labour force; and 3, the problems associated with specific outsider groups. While no specific groups, such as women or people of colour, are identified as needing to be included, the general thrust of the policy requires that institutions take note of the needs of those already excluded.

When this policy is translated into the university context, it has often been couched in terms of "affirmative action", where target groups are actively encouraged to participate in higher education. The Go8- the group of "sandstone" universities which consists of the oldest universities in Australia- has developed a social inclusion strategy group to develop policies for offering opportunities to "academically talented students from disadvantaged circumstances to advance through, and excel, in higher education." On the other hand, there are a number of universities in Australia which were part of a second foundation in the mid-twentieth century which were established primarily with social justice missions, to enable those from non-traditional backgrounds to enter higher education ( e.g. Griffith, Macquarie, Flinders, etc). These universities continue to have high entry levels of first -in -family, lower socio-economic, diverse cultural and ethnic backgrounds, and with a high proportion of women students.

What most universities are only now coming to terms with is the specific needs of the most excluded, those with disabilities or dual descriptions ( mental health issues + ethnicity; rural+ learning difficulties). Most of these issues are dealt with at the third level of policy- that created and maintained within the discrete educational unit- the school, faculty or group. The imperatives for social inclusion are already in place. Both the national policy and the university policy have to be incorporated into that adopted by the faculty, but often translating these into specific regulations is done on an ad hoc basis as problems arise. In many cases what appears to be an issue of social exclusion is, in reality, a lag between the recognition of the issue and developing workable means of dealing with it adequately.

Attempting to develop curriculum which is concerned with social inclusion has several aspects: first, a curriculum which explores the meaning and import of social inclusion; second, a curriculum which allows for the active participation of students from a wide range of backgrounds and levels of academic capital; and third, the process of recognising that curriculum is the means to transformation from exclusion to inclusion and that this can carry grave problems for many students whose circumstances impinge upon their progress. Developing a curriculum which enables students to think about the 
issues of inclusion/exclusion, equality/equity, sameness/difference often requires exploring more than the key content of a specific course, particularly in disciplines other than the social and behavioural sciences. In order for students to be able to access the advantages of social inclusion offered by a tertiary education also means developing courses, units and programs that support and allow for students who have little educational or academic capital upon entry, but who, with some nurturing can achieve results similar to students entering with substantially higher levels of skills and knowledge. The final issue here is that students will sometimes find it difficult to deal with learning that separates them from the familiar, from friends, family and the known. The reality is that higher education can be a transforming experience, and often there is little preparation for the changes in attitude, awareness, approach to the world that can result from even early contact with university life and learning. This issue requires some vigilance form educators if social inclusion policies are not to create anguish and isolation for students.

Practice then becomes an area for scrutiny, and here again there are several quite distinct facets to this. While policy may make provision for the inclusion of students from particular backgrounds, what actually happens on the ground? Are educators developing curricula which are inclusive both in content and in the process of inviting students to learn even where they have little foundation? Are the discrete units making policies that support the needs of those to be included? How far, for example, have universities come in making their campuses friendly for those with a disability? Or for ethnic or religious groups?

So how far have we come? For a millennium, universities in the West were key institutions in the careful maintenance of social exclusion. Those excluded were women, people of colour, those with disabilities, the poor, the ethnic or religious, or any number of groups or persons who were simply not "worthy". In the last century or so, women first, and later various other groups, have gradually been granted access to universities; often reluctantly, almost always after considerable agitation. The costs of education have fallen and risen, including and excluding according to the economics of the day. Policy has been instituted for social inclusion at the levels of government, universities and faculties, but have the practices actually changed. Do universities still only want the "academically talented" for inclusion, and as a reflection of their own institutional reputation? Are higher education and social inclusion permanently mutually exclusive?

Is this why many people say that the only education they will ever have is from the "University of Hard Knocks'?

\section{References}

Cervini, E., (2010). A woman's place. http://www.theage.com.au/national/education . Sept. 13,2010

Commonwealth of Australia. (2009). Social Inclusion: the origins, meaning, definition and economic implications of the concept social inclusion/exclusion. Canberra: Department of Education, Employment and Workplace Relations 
Dyhouse, C. (1995). No distinction of sex? Women in British universities, 1870-1939. London: UCL Press

Group of Eight Social Inclusion Strategy Group. (n.d). http://www.go8.edu.au/go8members/go8-committees/go8-social-inclusion-strategy-group

Milner-Thornton, J.B. (2012) The Long Shadow of the British Empire: the Ongoing Legacies of Race and Class in Zambia. New York: Palgrave Macmillan

Spender, D. (Ed). (1987). The Education Papers: Women's quest for equality in Britain 1850-1912 London: Routledge

\section{Biographical Note}

Dr Susanna Chamberlain is the convenor of the Social Enterprise core stream at Griffith University. Since 2008 she has been responsible for leading the development and implementation the suite of subjects which make up the core stream in the Bachelor of Arts. Her previous career was a Narrative Therapist and she taught Narrative Therapy and Community work for several years. Her lifelong commitment is to social justice and the development of personal potentials. 